\title{
Analisis Faktor-Faktor yang Mempengaruhi Indeks Pelaporan Keuangan Melalui Internet
}

\author{
Deasy Ratna Puri \\ Fakultas Ekonomi dan Bisnis Universitas Muhammadiyah Malang \\ Jl. Raya Tlogomas No. 246, Malang \\ E-mail:d345ydeluffy@gmail.com
}

\begin{abstract}
The two main purpose of this study are to describe the extent of internet financial reporting by leading Indonesian companies and to analize it's antecedents. The sample of this study is 48 companies that include on the biggest market capitalization for year of 2011 . This study uses secondary data which taken from the IDX fact book 2011 and 48 companies's official website. Internet Financial Reporting Index measured with four criterias, they are content, timeliness, tecnology, and user support. The result of this study shows that the profitability, liquidity, leverage, firm size, and public ownership haven't significant impact on the Internet Financial Reporting Index.
\end{abstract}

Keywords: internet financial reporting index, website, market capitalization

\section{PENDAHULUAN}

Dalam beberapa dekade terakhir ini perkembangan teknologi semakin berkembang pesat, terutama dalam bidang komunikasi. Perkembangan teknologi ini telah membawa perubahan bukan hanya dalam pola pikir masyarakat, tetapi juga cara bisnis suatu perusahaan dan bagaimana informasi dipertukarkan. Sejalan dengan cepatnya perkembangan bidang teknologi tersebut, perusahaan juga semakin terpacu untuk menggunakan teknologi yang maju sebagai senjata untuk tetap survive dan memenangkan persaingan yang kian hari terasa semakin ketat dan berat (Kusumawardani, 2011).

Internet merupakansalahsatupenemuanteknologiterbesar yang sangat mendukung perkembangan komunikasi (Hargyantoro, 2010). Perkembangan internet yang cepat telah mengubah cara bisnis suatu perusahaan. Internet menawarkan berbagai kemungkinan kepada perusahaan untuk menyajikan informasi keuangan dengan kuantitas yang lebih tinggi, biaya yang lebih murah dan bisa menjangkau para pemakai secara luas tanpa halangan geografis. Internet merupakan suatu media yang tepat untuk digunakan sebagai sarana mengakomodasi perubahan yang dibutuhkan dalam pelaporan perusahaan.

Penggunaan internet dalam dunia bisnis telah mempengaruhi bentuk tradisional penyajian informasi perusahaan. Selain itu perkembangan internet yang cepat menciptakan cara baru bagi perusahaan untuk berkomunikasi dengan investor. Internet yang digunakan perusahaan untuk melaporkan informasi keuangan kepada investor biasa disebut Internet Financial Reporting (IFR). Beberapa tahun belakangan ini, IFR muncul dan berkembang sebagai media yang paling cepat untuk menginformasikan hal-hal yang terkait dengan perusahaan.

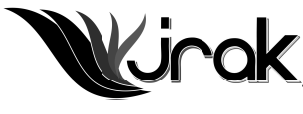

Jurnal Reviu Akuntans dan Keuangan ISSN: 2088-0685 Vol.3 No. 1, April 2013 Pp 383-390 
Analisis

Faktor-

Faktor...

384 sedang dalam periode paper-based reporting system ke paper-less reporting system.

Survei Khan (2006) terhadap 1000 perusahaan besar di Eropa menunjukkan bahwa $67 \%$ perusahaan telah mempunyai situs webdan $80 \%$ dari perusahaan yang mempunyai situs webtersebut mengungkapkan laporan keuangan di internet. Penelitian lain mengungkapkan 56\% dari perusahaan Mesir melaporkan sebagian besar informasi di situs webperusahaan (Aly et al, 2010). Hingga tahun 2006, lebih dari 70\% perusahaan besar di dunia menerapkan IFR (K han, 2006).

Berbagai alasan yang mendasari kebijakan perusahaan untuk melakukan pelaporan keuangan melalui internet (IFR), terkait kepentingan finansial atau non-finasial.Alasan tersebut disebabkan oleh faktor-faktor potensial yang mempengaruhi kebijakan perusahaan untuk melakukan pelaporan keuangan melal ui internet (IFR). Penggunaan internet relevan dalam meningkatkan transparasi informasi yang diberikan oleh perusahaan yang pada akhirnya akan meningkatkan corporate governance (Sayogo, 2005).

Sedangkan penelitian sejenis yang dilakukan oleh Kusumawardani (2011) untuk menganalisis faktor-faktor yang mempengaruhi pelaporan keuangan melalui internet dalam situs web perusahaandilakukan dengan analisis multivariat dengan menggunakan regresi logistik (logistic regression) untuk pengujian hipotesisnya, variabel bebas yang dipilih merupakan kombinasi antara metric dan non metric (nominal) (Ghozali, 2007) dan tidak memerlukan uji normalitas dan uji asumsi klasik pada variabel bebasnya. Berdasarkan penelitian tersebut disimpulkan bahwa variabel profitabilitas dan public ownership berpengaruh secara positif dan signifikan terhadap praktik pelaporan keuangan melalui internet (Internet Financial Reporting). Sedangkan variabel ukuran perusahaan, likuiditas, jenis industri, leverage, reputasi auditor, umur listing, serta foreign ownership tidak terbukti berpengaruh secara signifikan terhadap praktik pelaporan keuangan melalui internet (Internet Financial Reporting).

Berbagai penelitian yang telah dilakukan berkaitan dengan IFR. Variabel yang diteliti oleh peneliti terdahulu meliputi Iaporan keuangan lengkap dan financial highlight (Almilia, 2009), profitabilitas, likui ditas, leverage, jenis industri, pemilikan saham publik dan umur perusahaan, pemilikan sahamasing dan ukuran auditor (Aly et al., 2010), CSR, risk management, dan corporate governance (Khan, 2006).Penelitian ini menggunakan variabel profitabilitas, likuiditas, laverage, ukuran perusahaan, pemilikan saham publik dan pemilikan saham asing. Variabel tersebut dipilih berdasarkan tingginya intensitas penggunaan variabel dalam penelitian yang telah dilakukan.

Analisis faktor yang berpengaruh pada indeks pelaporan keuangan perusahaan ini menjadi penting untuk dilakukan karenamasih adanya hasil penelitian yang kontroversi, seperti yang telah diuraikan pada riset terdahulu diatas dan untuk membuktikan konsistensi dari penelitian sebelumnya.

Berdasarkan uraian tersebut, maka penelitian ini akan mengidentifikasi dan menganalisis faktor-faktor yang berpengaruh pada pelaporan keuangan melalui internet dengan nilai kapital isasi pasar (market capitalization) terbesar di Indonesia. Pemilihan perusahaan dengan nilai kapitalisasi pasar (market capitalization) terbesar didasarkan karena semakin akurat dan relevannya informasi yang diungkapkan dalam pelaporan keuangan melalui internet maka tingkat perdagangan saham cenderung semakin tinggi dan berdampak pada tingkat harga saham atas jumlah saham yang diterbitkan cenderung naik (outstanding check). $\mathrm{Hal}$ ini menunjukkan bahwa pelaporan keuangan melalui internet memiliki peran terhadap nilai kapitalisasi suatu perusahaan. 


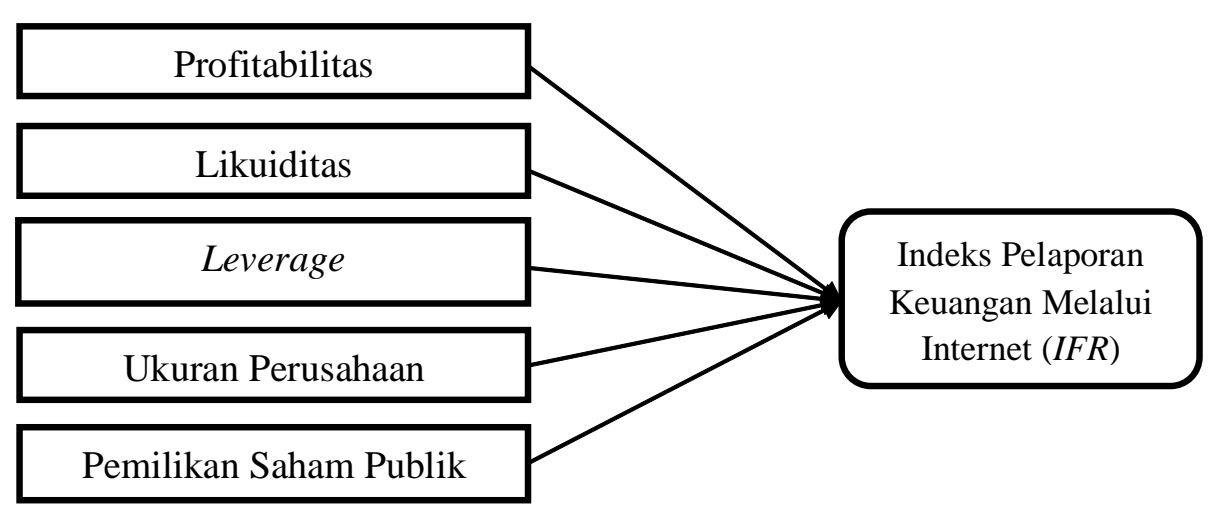

\section{METODE}

Data yang digunakan dalam penelitian ini adalah data sekunder, yaitu data yang di per ol eh/dikumpulkan dan disatukan ol eh studi-studi sebel umnya atau yang diterbitkan oleh berbagai instansi terkait. Data sekunder yang digunakan dalam penelitian ini adalah informasi keuangan dan non keuangan yang terdapat dalam situs perusahaan dan daftar leading companies yang di perol eh dari I DX F act 20102011.

Sumber data penelitian ini diperoleh dari:

1. Indonesia Stock Exchange (IDX) Fact 2010-2011

2. Bursa Efek Indonesia (BEI)

3. Situs perusahaan

4. Buku teks, artikel dan penelitian terdahulu yang terkait dengan penelitian.

\section{Teknik Perolehan Data}

Dalam penelitian ini pengumpulan data dilakukan dengan metode dokumentasi pada Indonesia Stock Exchange (IDX) Fact 2011 untuk memperoleh daftar perusahaan yang termasuk dalam perusahaan dengan nilai kapitali sasi pasar terbesar tahun 2011.

\begin{tabular}{|c|c|c|}
\hline No. & Keterangan & $\begin{array}{c}\text { Jumlah } \\
2011\end{array}$ \\
\hline 1. & 50 perusahaan dengan nilai kapitalisasi terbesar & 50 \\
\hline 2. & Memiliki situs web resmi (officiall website) yang dapat diakses & 49 \\
\hline
\end{tabular}

\section{Definisi Operasional dan Pengukuran Variabel}

1. Variabel Independen

a. Profitabilitas, diukur dengan menggunakan Return on Equity (ROE). Return On Equity (ROE), yaitu perbandingan antara laba bersih dengan total ekuitas.

b. Likuiditas, merupakan likuiditas minimum yang harus dipelihara oleh perusahaan dalam membayar kembali kewajiban jangka pendek perusahaan, diukur dengan menggunakan Rasio Kas (Cash Ratio), yaituperbandingan antara jumlah kas dan setara kas yang dimiliki perusahaan dengan jumlah hutang lancar.

c. Leverage, diukur dengan menggunakan Debt to Equity Ratio (DER) yang merupakan imbangan antara hutang yang dimiliki perusahaan dengan modal sendiri.

d. Ukuran Perusahaan, diukur dengan nilai kapitalisasi pasar (market capitalization). 
Analisis

Faktor-

Faktor...

386 e. Pemilikan Saham Publik, diukur dengan membagi jumlah saham yang dimiliki publik dengan total saham (modal dasar).

2. Variabel Dependen

Variabel dependen dalam penelitian ini adalah indeks pelaporan keuangan melalui internet. Variabel ini diukur dengan menggunakan kriteria penilaian menurut Chan dan Wickramasinghe (2006). Variabel ini diukur dengan menggunakan:

a. Isi laporan keuangan (content)

Isi laporan keuangan memiliki kriteria penilaian sebesar 40\%. J ika informasi keuangan diungkapkan dengan format HTML maka skor yang dinilai lebih tinggi yaitu 2 poin dibandingkan dalam format PDF yaitu 1 poin. Hal ini disebabkan penggunaan tekonologi web berupa format HTM L lebi h memudahkan pengguna untuk mengakses informasi secara efektif.

b. Waktu pelaporan keuangan (timeliness)

Waktu pelaporan keuangan memiliki kriteria penilaian sebesar $20 \%$. Untuk pengungkapan siaran pers dan harga saham, terdapat nilai tambah bagi informasi baru (pada skala 0 sampai 3). Perusahaan juga menerima skor untuk pengungkapan Hasil triwulan terbaru yang telah diaudit dan pernyataan visi perusahaan/pernyataan perkiraan masa depan.

c. Teknologi yang digunakan (techonology index)

Teknologi yang digunakan memiliki kriteria penilaian sebesar $20 \%$.Teknologi yang digunakan meliputi item-item yang ridak dapat disediakan oleh laporan tercetak antara lain downl oad plug-in, umpan balik secara online, penggunaan slide presentasi, penggunaan teknologi multimedia (audio dan video), alat analisis dan fitur yang canggih (misal nya XBRL).

d. Fasilitas pendukung web (user support)

Para pengguna memiliki keterampilan berbeda dalam mengoperasikan komputer diantaranya pemula hingga ahli. Perusahaan yang menerapkan alat yang mana memfasilitasi pengguna I FR mendapatkan skor lebih tinggi . Teknol ogi yang digunakan memi liki kriteria penilaian sebesar $20 \%$. Alat-alat yang dinilai dalam indeks antara lain pencarian dan alat navigasi (seperti FAQ, link ke halaman utama, Link ke atas, Situs peta, Situs pencari), jumlah klik untuk mendapatkan informasi keuangan (pada skala 0 sampai 3), serta konsistensi desain halaman web.

Sehingga penilaian skor indeks pelaporan keuangan internet melalui IFR Disclosure Scores yaitu:

$I F R-D S=\left(\frac{\text { Score }}{\text { Max }} \%\right.$ CONT $)+\left(\frac{\text { Score }}{\text { Max }} \%\right.$ TIME $)+\left(\frac{\text { Score }}{\text { Max }} \% T E C H\right)+\left(\frac{\text { Score }}{\text { Max }} \%\right.$ SUPP $)$

Dimana:

Score $=$ Skor/nilai total setiap komponen pengungkapan

Max = Skor/nilai maksimal setiap komponen pengungkapan

$\%$ CONT $=$ Proporsi kriteria penilaian isi laporan keuangansebesar $40 \%$

\%TIME = Proporsi kriteria penilaian waktupelaporan keuangan sebesar $20 \%$

$\% \mathrm{TECH}=$ Proporsi kriteria penilaian teknologi sebesar $20 \%$

$\%$ SUPP $=$ Proporsi kriteria penilaian dukungan pengguna sebesar $20 \%$ 
1. Melakukan pengukuran IFR Index

2. Pengukuran variabel independen

3. Tabulasi Data

4. Uji Statistik Deskriptif

5. Uji Asumsi Klasik

6. Analisis Regresi Linier Berganda

7. Uji Model

8. AnalisisDeskriptif Kualitatif

\section{HASIL DAN PEMBAHASAN}

\section{Analisis Data}

Analisis data dimulai dengan melakukan pengukuran IFR index. Pengukuran ini dilakukan untuk menilai penyajian IFR. Pengukuran Indeks pelaporan keuangan melalui internet menggunakan alat pengungkapan IFR (IFR Disclosure Instruments). Penel iti mengukur IFR Index dengan empat kriteria pengungkapan dengan item masing-masing yang meliputi (1) Isi laporan keuangan (content) (2) Ketepatan waktu pelaporan keuangan (timeliness) (3) Teknologi yang digunakan (techonology) dan (4) Fasilitas pendukung web (user support).

Setelah itu kemudian melakukan perhitungan variabel independen (profitabilitas, likuiditas, Leverage, ukuran perusahaan dan pemilikan saham publik), kemudian dilakukan tabulasi data sebagai bahan untuk melakukan uji regresi. Tabel 3 menyajikan hasil perhitungan regresi.

Coefficients $^{\mathrm{a}}$

\begin{tabular}{|c|c|c|c|c|c|c|c|c|}
\hline & \multirow[t]{2}{*}{ Model } & \multicolumn{2}{|c|}{ Unstandardized Coefficients } & \multirow{2}{*}{$\begin{array}{r}\begin{array}{c}\text { Standardized } \\
\text { Coefficients }\end{array} \\
\text { Beta }\end{array}$} & \multirow[t]{2}{*}{$\mathbf{T}$} & \multirow[t]{2}{*}{ Sig. } & \multicolumn{2}{|c|}{$\begin{array}{l}\text { Collinearity } \\
\text { Statistics }\end{array}$} \\
\hline & & B & Std. Error & & & & Tolerance & VIF \\
\hline \multirow[t]{6}{*}{1} & (Constant) & .340 & .699 & & .486 & .629 & & \\
\hline & Profitabilitas & -1.018 & .839 & -.244 & -1.214 & .231 & .544 & 1.840 \\
\hline & Likuiditas & 0.342 & .001 & .017 & .103 & .919 & .809 & 1.237 \\
\hline & Leverage & -.002 & .008 & -.047 & -.226 & .822 & .509 & 1.965 \\
\hline & Ukuran_Perusahaan & .020 & .053 & .061 & .378 & .707 & .839 & 1.192 \\
\hline & Saham_Publik & -.241 & 175 & -.206 & -1.378 & .176 & .980 & 1.021 \\
\hline
\end{tabular}

Tabel 3:

Hasil Perhitungan

Regresi Linier

Berganda

a. Dependent Variable: Indeks_IFR

R Square $=.077$

$\mathrm{F}=.700 \mathrm{sig}=.627$

\section{Pembahasan}

Sampel yang digunakan dalam penelitian ini adalah 48 perusahaan yang termasuk dalam 50 Leading Companies In Market Capitalizati on tahun 2011 dan memiliki situs web resmi yang dapat diakses. Sedangkan data yang digunakan pada peneletian ini adalah seluruh informasi finansial dan non-finansial yang telah diungkapkan ol eh perusahaan dalam masing-masing situs web perusahaan.

Peneliti ingin menguji konsistensi dari berbagai penelitian terdahulu tentang pengaruh berbagai faktor terhadap Indeks pelaporan keuangan melalui internet (IFR Index) menggunakan uji regresi linier berganda. Dengan variabel independen profitabilitas, likuiditas, Leverage, ukuran perusahaan dan pemilikan saham publik serta variabel dependen Indeks IFR, hasil uji signifikan adalah sebesar 0,235. Karena pengujian menggunakan tingkat signifikansi 0,05, maka dapat diketahui bahwa signifikansi $>0,05$,sehingga seluruh hipotesis ditolak. Hal ini dapat menya- 
Analisis

Faktor-

Faktor...

388 takan bahwa tidak terdapat pengaruh antara profitabilitas, likuiditas, Leverage, ukuran perusahaan dan pemilikan saham publik terhadap indeks pelaporan keuangan melalui internet (IFR Index) pada perusahaan dengan nilai kapitalisasi pasar terbesar tahun 2011.

Penelitian ini konsisten dengan penelitian yang dilakukan oleh Kusumawardani (2011) untuk menganalisis faktor-faktor yang mempengaruhi pelaporan keuangan melalui internet dalam situs web perusahaan. Pengujian hipotesis dilakukan dengan analisis multivariat dengan menggunakan regresi logistik (logistic regression), yang variabel bebasnya merupakan kombinasi antara metric dan non metric (nominal) (Ghozali, 2007) dan tidak memerlukan uji normalitas dan uji asumsi klasik pada variabel bebasnya. Berdasarkan penelitian tersebut disimpulkan bahwa variabel ukuran perusahaan, likuiditas, jenis industri, Leverage, reputasi auditor, umur listing, serta foreign ownership tidak terbukti berpengaruh secara signifikan terhadap praktik pelaporan keuangan melalui internet (Internet Financial Reporting).

Penelitian ini juga konsisten terhadap penel itian sebel umnya yang menyatakan tidak terdapat hubungan yang signifikan antara porsi pemilikan saham publik dengan kelengkapan pelaporan keuangan artinya porsi pemilikan saham publik tidak dapat dijadikan ukuran bahwa laporan keuangan perusahaan memiliki kualitas pengungkapan yang lengkap, dibuktikan juga bahwa tingkat Leveragedan ukuran perusahaan tidak berpengaruh terhadap pengungkapan sukarela. (Rahmawati, 2010).

Penyebab tidak adanya pengaruh yang signifikan antara faktor-faktor terkait (profitabilitas, likuiditas, Leverage, ukuran perusahaan dan pemilikan saham publik) terhadap indeks pelaporan keuangan melal ui internet (IF R Index) dapat kita hubungkan dengan sifat pelaporan keuangan melalui internet dan biaya pengel olaan data.

1. Sifat pelaporan keuangan melalui internet (Internet Financial Reporting).

Seperti yang telah dipaparkan sebelumnya pada Iandasan teori bahwa jenis pengungkapan terbagi menjadi pengungkapan wajib (Mandatory Disclosure) dan pengungkapan sukarela (Voluntary Disclosure). Pelaporan keuangan meIalui internet adalah salah satu pelaporan yang dilakukan secara sukarela, karena sifatnya yang sukarela ini, banyak perusahaan yang merasa tidak perlu melakukan praktek IFR.Tidak seperti pengungkapan wajib (mandatory disclosure) yang sifatnya memaksa sehingga perusahaan sangat berkepentingan untuk melaksanakannya sebagai komponen pendukung berjalannya usaha yang didirikan. Argumen yang sama telah diungkapkan ol eh Suwardjono (2008) bahwa pengungkapan sukarela adalah pengungkapan yang dilakukan ol eh perusahaan diluar apa yang telah di wajibkan ol eh standar akuntansi atau peraturan badan pengawas. Sehingga tidak semua perusahaan melakukan praktik pengungkapan yang sama, namun sesuai dengan kebutuhan perusahaan tersebut.

2. Biaya Pengelolaan

Disamping IFR bukan pengungkapan wajib, hal lain yang dipandang mendukung untuk tidak menjalankan praktek IFR adalah adanya biaya pengeIolaan informasi yang disajikan melalui masing-masing web. Telah menjadi hukum alam dal am dunia bisnis jika bi aya yang dikeluarkan semakin tinggi, maka laba yang dihasilkan akan semakin rendah. Setiap perusahaan memiliki kebijakan masing-masing untuk tidak melakukan praktek IFR, manajemenakan sel alu memperti mbangkan cost and benefit dari tiap keputusan yang diambil. Pertimbangan manajemen untuk mengungkapkan informasi secara sukarela dipengaruhi oleh faktor biaya. Manajemen mengambil keputusan untuk tidak melakukan praktek IFR dapat dikarenakan pihak manajemen berfikir tidak akanada manfaat langsung terhadap bisnis yang dijalankan. Walau pun ditemukan tidak sedikit perusahaan yang melakukan praktek IFR sekedar untuk menjaga citra perusahaan seperti yang telah diungkapkan 
Suwardjono (2008) bahwa manajemen juga akan menyampaikan informasi yang dapat meningkatkan kredibilitas dan kemajuan perusahaan meskipun informasi tersebut tidak diwajibkan. Hal ini didukung oleh penelitian Ashbaugh et al .,(1999) tentang pelaporan perusahaan melalui internet yang menyatakan bahwa selain memberikan beberapa keuntungan, pengungkapan informasi keuangan melalui situs web perusahaan juga memiliki beberapa kekurangan, antar lain:

a. Biaya untuk membangun serta merawat situs web terkadang melebihi atas manfaat yang didapat.

b. Sehubungan dengan market competition, dengan diungkapkannya informasi secara luas, perusahaan akan berpotensi kehilangan keunggulan kompetitifnya.

Argumen tersebut yang mengungkapkan bahwa biaya pengel olaan merupakan salah satu penyebab tidak berpengaruhnya faktor-faktor terkait (profitabilitas, likuiditas, leverage, ukuran perusahaan dan pemilikan saham publik) terhadap indeks pelaporan keuangan melalui internet (IFR Index) sehingga perusahaan tidak melakukan praktek IF R secara lengkap. Hal tersebut juga didukung dengan hasil panelitian ini yang menemukan bahwa pengungkapan I ndeks I F R dalam kriteria technology memiliki presentasi terkecil dalam pengungkapan tiap perusahaan jika dibandingkan dengan tiga kriteria lainnya. Karena untuk melengkapi kriteria technology yang terdiri dari item-item penggunaan teknol ogi multimedia, fitur canggih, al at analisis, dan umpan balik secara online, memerlukan biaya pengelolaan yang besar.

\section{SIMPULAN}

Berdasarkan hasil penelitian yang telah dilakukan, dapat disimpulkan bahwa:

Profitabilitas, Likuiditas, Leverage, Ukuran Perusahaan, dan Pemilikan Saham Publik tidak berpengaruh secara signifikan terhadap Indeks pelaporan keuangan melalui internet yang akan diungkapkan ol eh 50 Leading Companies In Market Capitalization yang terdaftar di IDX. Hal ini terbukti dengan dari berbagai hasil pengujian yang diantaranya:

1. Perusahaan dengan profitabilitas yang tinggi mengungkapkan Indeks pelaporan yang rendah, hal ini membuktikan bahwa dengan profitabilitas yang tinggi tidak menjamin perusahaan akan mengungkapkan indeks pelaporan keuangan melalui internet secara lengkap.

2. Dari empat kriterial FR Indeks yang diukur, kriteria technology memiliki presentasi terkecil dari setiap perusahaan, hal ini dikarenakan situs web yang dimiliki perusahaan hanya menampilkan IFR Indeks standar, yaitu hanya maksimal pada pengungkapan kriteria content saja yang item-itemnya terpenuhi hanya pada bentuk pelaporan wajib (mandatory) berupa laporan keuangan lengkap.

3. Dari 48 perusahaan dengan ukuran yang besar, 17 perusahaan diantaranya memiliki pengungkapan IFR Indeks yang rendah yaitu dibawah rata-rata $56,75 \%$. Hal ini dapat dibuktikan dengan membandingkan antara Astra Internasional Tbk. sebagai perusahaan dengan ukuran terbesar yang mengungkapkan informasi keuangan berdasarkan IFR Indeks sebesar 53,92\% dengan Holcim Indonesia yang berada di urutan 37 dari 50 perusahaan yang ada, mengungkapkan informasi keuangan berdasarkan IFR I ndeks tertinggi sebesar 78,75\%. Perbandingan presentasi yang cukup si gnifikan untuk ukuran perusahaan terbesar seperti Astra Internasional Tbk, hal ini menyimpulkan bahwa ukuran perusahaan tidak berpengaruh secara signifikan terhadap presentasi pelaporan keuangan perusahaan melalui internet. 
Analisis

Faktor-

Faktor...

390

\section{DAFTAR PUSTAKA}

Almilia, L.S. 2009. "Analisa Kualitas I si Financial and Sustainbility Reporting pada Situs Web Perusahaan Go Publik di Indonesia". Seminar Nasional Aplikasi Teknologi Informasi 2009 (SNATI 2009), Yogyakarta.

Aly, D., Simon, J . \& Hussainey, K. 2010. "Determinants of Corporate Internet Reporting: E vidence from Egypt". Managerial Auditing J ournal, 25(2) 182-202.

Ashbaugh, H., J ohnstone, K.M., and Warfield T.D. 1999. "Corporate Reporting on the Internet". Accounting Horizons. Vol. 13 No.3. pp. 241-257.

Ghozali, L. 2007. Aplikasi Analisis Multivariate dengan Program SPSS. Badan Peneliti Universitas Diponegoro.

Hanifa, M.H., \& Ab. Rashid, H. 2005. “The Determinants of Vol untary Disclosures in Malaysia: The Case of I nternet Financial Reporting". UNITAR E-J ournal, 2(1), 22-42.

Hargyantoro, Febrian. 2010. “Pengaruh I nternet Financial Reporitng dan Tingkat Pengungkapan Informasi Situs Web Terhadap Frekuensi Perdagangan Saham Perusahaan". Skripsi pada Sarjana Akuntansi Uninersitas Diponegoro Semarang.

Khan, T. 2006. Financial Reporting Disclosure on the Internet: An International Perspective. Unpublished doctoral dissertation,Victoria University, F ootscray Park, Victoria, Australia.

Kusumawardani, Arum. 2011. "Analisis Faktor-faktor yang Mempengaruhi Pelaporan Keuangan Melalui Internet (Internet Financial Reporting) dalam Situs Web Perusahaan". Skripsi pada Sarjana Akuntansi Universitas Diponegoro. Semarang.

Rahmawati, Lazuarna. 2010. “Pengaruh Karakteristik Perusahaan Terhadap Luas Pengungkapan Sukarela (Voluntary Disclosure) pada Perusahaan Publik di Indonesia". Skripsi pada Sarjana Akuntansi Universitas Muhammadiyah Malang.

Sayogo, D.S. 2005. "Faktor-faktor yang Mempengaruhi Disclosure Tentang Corporate Governance melalui I nternet pada Perusahaan yang Terdaftar di Bursa Efek J akarta". Lemlit UM M. Malang.

Suwardjono. 2008. Teori Akuntansi Perekayasaan Pelaporan Keuangan, Edisi Ketiga. BPFE.Yogyakarta. 